This is the author's final, peer-reviewed manuscript as accepted for publication. The publisher-formatted version may be available through the publisher's web site or your institution's library.

\title{
Effects of Nitrogen and Planting Seed Size on Cotton Growth, Development, and Yield
}

Christopher L. Main, L. Tomas Barber, Randall K. Boman, Kent Chapman, Darrin M. Dodds, Stu Duncan, Keith L. Edmisten, Patrick Horn, Michael A. Jones, Gaylon D. Morgan, E. Randall Norton, Shane Osborne, Jared R. Whitaker, Robert L. Nichols, and Kevin F. Bronson

\section{How to cite this manuscript}

If you make reference to this version of the manuscript, use the following information:

Main, C. L., Barber, L. T., Boman, R. K., Chapman, K., Dodds, D. M., Duncan, S., Edmisten, K. L., Horn, P., Jones, M. A., Morgan, G. D., Norton, E. R., Osborne, S., Whitaker, J. R., Nichols, R. L., \& Bronson, K. F. (2013). Effects of Nitrogen and Planting Seed Size on Cotton Growth, Development, and Yield.

\section{Published Version Information}

Citation: Main, C. L., Barber, L. T., Boman, R. K., Chapman, K., Dodds, D. M., Duncan, S., Edmisten, K. L., Horn, P., Jones, M. A., Morgan, G. D., Norton, E. R., Osborne, S., Whitaker, J. R., Nichols, R. L., \& Bronson, K. F. (2013). Effects of Nitrogen and Planting Seed Size on Cotton Growth, Development, and Yield. Agronomy Journal, 105(6), 1853-1859.

Digital Object Identifier (DOI): 10.2134/agronj2013.0154 ER

Publisher's Link:

https://www.agronomy.org/publications/aj/abstracts/105/6/1853? search-result=1

This item was retrieved from the K-State Research Exchange (K-REx), the institutional repository of Kansas State University. K-REx is available at http://krex.ksu.edu 


\section{Effects of Nitrogen and Planting Seed Size on Cotton}

\section{Lint Yield, Fiber Quality, Seed Protein, and Oil Content}

C. L. Main ${ }^{1}$, L. T. Barber ${ }^{2}$, R. K. Boman ${ }^{3}$, K. Chapman ${ }^{4}$, D. M. Dodds ${ }^{5}$, S. Duncan ${ }^{6}$, K. L. Edmisten $^{7}$, P. Horn ${ }^{4}$, M. A. Jones ${ }^{8}$, G. D. Morgan ${ }^{9}$, E. R. Norton ${ }^{10}$, S. Osborne ${ }^{11}$, J. R.Whitaker ${ }^{12}$, and R. L. Nichols ${ }^{13}$

${ }^{1}$ Univ. of Tennessee, ${ }^{2}$ Univ. of Arkansas, ${ }^{3}$ formerly of Texas A\&M Univ., now Oklahoma State Univ., ${ }^{4}$ North Texas State Univ., ${ }^{5}$ Mississippi State Univ., ${ }^{6}$ Kansas State Univ., ${ }^{7}$ North Carolina State Univ., ${ }^{8}$ Clemson University, ${ }^{9}$ Texas A\&M Univ., ${ }^{10}$ Univ. of Arizona, ${ }^{11}$ Oklahoma State Univ., ${ }^{12}$ Univ. of Georgia ${ }^{13}$ Cotton Incorporated

\section{$\underline{\text { Abstract }}$}

Nitrogen $(\mathrm{N})$ is often the nutrient applied to cotton (Gossypium hirsutum) in the largest amount, but also the one most subject to movement in the environment. Several U. S. states have recommended $110 \mathrm{~kg} \mathrm{~N} / \mathrm{Mg}$ lint to achieve maximum lint yields. However, contemporary cotton varieties have small seeds and high lint to seed cotton ratios; such varieties may require less $\mathrm{N}$ than did formerly popular varieties with larger seeds because the cottonseed contains a large fraction of the plant's nitrogen partition. A common experiment was conducted in 2009 and 2010 at 20 location-years across U.S. cotton producing states. The objectives of this research were to evaluate the utility of measuring pre-plant soil nitrate for estimating cotton's $\mathrm{N}$ requirements in arid and humid environments; and to determine the effect of $\mathrm{N}$ rates on lint yield, and the seed protein and oil content of locally-adapted cotton varieties that differed in seed size. Treatments were varieties with planting seed of three different counts (number of seed $\mathrm{kg}^{-1}$ ) and $\mathrm{N}$ rates of 0 , 45,90 , and $134 \mathrm{~kg} \mathrm{ha}^{-1}$. Lint yield responded to applied $\mathrm{N}$ at 11 of 20 trial sites. High levels of soil nitrate (>91 N-NO$\left.{ }_{3}^{-} \mathrm{kg} \mathrm{ha}^{-1}\right)$ were found at two western sites, and soil nitrates in the range of $45-73 \mathrm{~kg} \mathrm{~N}-\mathrm{NO}_{3}{ }^{-} \mathrm{ha}^{-1}$ were found at locations in the central U.S. Nitrogen increased plant height and number of fruiting nodes, decreased crop maturity as observed at 120 days after planting, increased seed weight and lint yields up to a optimum rate of $150 \mathrm{~kg} \mathrm{ha}^{-1}$ of applied N 
plus pre-plant, residual soil $\mathrm{NO}_{3}{ }^{-}$. Considering only sites that responded to $\mathrm{N}$, equivalent lint yields were achieved with $112-224 \mathrm{~kg} \mathrm{ha}^{-1}$ of applied plus pre-plant residual soil $\mathrm{NO}_{3}{ }^{-}$translating to an $\mathrm{N}$ requirement of $23 \mathrm{~kg} \mathrm{ha}^{-1}$ per $218 \mathrm{~kg}$ bale of lint produced. Among the varieties tested those with medium sized seed produced higher yields in response to $\mathrm{N}$ than did larger and smaller seeded varieties. Varieties with larger seed had longer and stronger fibers, higher fiber length uniformity than small seeded varieties and decreased micronaire. Contrary the original hypothesis no significant interactions of planting seed size and $\mathrm{N}$ rate were found. Seed protein and oil increased and decreased slightly in response increasing amounts of soil nitrate plus applied $\mathrm{N}$, respectively.

\section{$\underline{\text { Introduction }}$}

Nitrogen $(\mathrm{N})$ is frequently the plant nutrient provided to cotton in the greatest quantity, but often $\mathrm{N}$ is not utilized efficiently by the crop (Hunt et al., 1998; Hutmacher, 2004). Applied N may not be available to the crop because of runoff, leaching and volatilization. Such losses represent unrecovered input costs for the grower and potentially detrimental effects to the environment (Galloway et al. 2008). Moreover, in recent years prices of $\mathrm{N}$ fertilizers have increased and have been increasingly volatile (USDA-ERS, 2012). Thus there are both economic and environmental motives for increasing the efficiency of $\mathrm{N}$ fertilization practices.

A problem with selecting an optimum $\mathrm{N}$ rate for cotton is the plant's physiology. In contrast to grain crops that were selected from wild annual plants, cotton varieties are derived from arborescent perennials and are highly indeterminate in growth and reproduction patterns (Donald and Hamblin, 1976; Bednarz and Nichols, 2005). Partitioning of $\mathrm{N}$ in cotton is affected by genetics, environment, and the availability of N (Mullins and Burmeister, 1990; Boquet et al., 
1993; Boquet and Breitenbeck, 2000; and Fritschi et al., 2003). Cotton varieties that receive supraoptimal $\mathrm{N}$ may produce excessive vegetative growth and fewer reproductive structures than cotton receiving less N (Boquet et al., 1994; Boquet and Breitenbeck, 2000). Increasing N fertilization may increase cottonseed yields more than lint yields (Engelkraut et al., 2003; Fritschi et al., 2003).

Cotton lint is comprised of fibers growing from the cotton seed surface. Because a large number of small seed can have more surface area than do a few large seed, greater lint yields might be achieved by selecting for reduced seed size and increasing seed numbers (Harell and Culp, 1976). Such a result could accrue from simple selection for high gin turnout, the fraction of lint obtained from harvested seed cotton. In fact the mean seed size of cotton varieties has been decreasing for the last 30 years (Bednarz et al., 2007).

The cotton crop produces lint, whole seed for ruminant feed, cottonseed meal, a source of protein, and cottonseed oil, as well as hulls, a source of roughage, and linters, a source of cellulose. Since cotton seeds are an N sink (Engelkraut et al., 2003), maximum lint yields might be achieved with lower rates of $\mathrm{N}$ than previously were recommended for cotton production. Use of relatively low $\mathrm{N}$ rates for the fertilization of small-seeded cotton varieties may change the distribution of products produced by cotton and the distribution of $\mathrm{N}$ among cotton product from that expected with larger seeded varieties.

\section{$\underline{\text { Materials and Methods }}$}

A common experiment was conducted by state co-operative extension cotton specialists at 20 locations during 2009 and 2010 (Table 1.). At each location, the experiment was implemented as a factorial arrangement of three varieties and four $\mathrm{N}$ rates within a randomized complete block 
design with four replications of treatments. The three cotton seed size classes were selected with counts $\mathrm{kg}^{-1}$ in the following ranges, less than 9702 , between $9703-11,025$, and greater than 11,026. A locally-adapted variety from each seed-size class was selected at each location. Nitrogen rates were $0,45,90$, and $134 \mathrm{~kg} \mathrm{~N} \mathrm{ha}^{-1}$ applied as a side-dress treatment between planting and the pinhead square stage of cotton development. Nitrogen fertilizer source was selected at each trial location according to locally available sources and practices.

The cations, $\mathrm{Ca}, \mathrm{Mg}$, and $\mathrm{K}$; and extractable $\mathrm{P}$ were determined according to state soil laboratory procedures in the respective states. Except as noted in the experimental design, the crops were managed for high yields according to each respective states University Extension recommendations. Soil samples were extracted from each plot at the 0-15 and $15-60 \mathrm{~cm}$ depth before planting and $\mathrm{N}$ application. Soil nitrate was determined in all samples (Bremner, 1965). Stand counts were recorded 10-14 days after planting (DAP) to insure a uniform crop was established for each trial. Cotton vigor was monitored by recording the number of nodes above the highest first position white flower (NAWF) weekly from first bloom through defoliation (Bourland et al, 2001). At 120 days after planting plant height, number of plant nodes, number of bolls, and nodes above the highest first position cracked boll (NACB) to the highest harvestable boll were recorded (Bourland et al, 1994). The date when each treatment reached $60 \%$ open boll was recorded, and the cotton defoliated as soon thereafter as possible. The two center rows of each plot were harvested using spindle pickers modified for small-plot harvesting at all locations except in Altus, OK and Lubbock, TX where a cotton stripper harvester was used. A sample of mechanically harvested seedcotton was collected from each plot and used to determine lint percentage and fiber quality. Gin turnout and lint yields were recorded, and ginned $50 \mathrm{~g}$ lint samples were sent to Cotton Incorporated where fiber properties measured using a Model 1000 
Uster High Volume Instrument (Sasser, 1981). Fuzzy cotton seed index was determined by counting the number of ginned seed in three 100-g samples.

Oil and protein content of the seed were quantified in samples of fuzzy seed by chemometric analysis using pulsed-field, time-domain ${ }^{1} \mathrm{H}$ nuclear magnetic resonance (TD-NMR) as previously developed (Horn et al., 2011) with a few modifications. The NMR signals were recorded on a modified Bruker minispec mq20 NMR analyzer (Bruker Optics, Inc, The Woodlands, TX). A newly-designed probe (PA247) with shorter dead time (29 $\mu$ sec) was installed in the mq20 spectrometer to acquire additional solid-echo signal and enhanced overall signal quality that improved the prediction of protein values from cottonseed. Algorithms for the calculation of oil and protein values were developed by generating a standard curve or by multivariate analysis, respectively, with a diverse reference seed set. Values for each sample were reported as mean weight percent from three independent samples of approximately $3 \mathrm{~g}$ of seed.

Data were subjected to statistical analysis using the PROC MIXED procedure of the Statistical Analysis System (SAS ${ }^{\circledR}$ version 9.2; SAS® Institute Inc.; Cary, NC). A preliminary analysis reviled no interaction of the main effects, seed-size classes and $\mathrm{N}$ rates with locations and years. Each year-location combination was considered an environment. Environments, replications nested within environment, and all interactions of these effects were considered random effects; whereas nitrogen and variety treatment were considered fixed effects. Considering environments as a random effect permits inferences about the treatments to be made over a range of environments (Blouin, 2011; Carmer et al.,1989). A similar statistical approach has been used by several researchers utilizing a randomized complete block design (Bond et al., 2005; Hager et al., 2003; Jenkins et al., 1990) as well as those utilizing a factorial arrangement of treatments in a 
randomized complete block design (Bond et al., 2008; Ottis et al., 2004; Walker et al., 2008). Means were separated using Fishers Protected LSD test at the 0.05 significance level.

\section{$\underline{\text { Results and Discussion }}$}

\section{$\underline{\text { Soil Nitrate Measurements }}$}

Results from analysis of soil nitrate varied based on soil type and nitrogen use history (Figure 1). Sandy loam soils in Georgia, North Carolina, and South Carolina with previous nitrogen use contained from 17-22 $\mathrm{kg} \mathrm{NO}_{3}^{-} \mathrm{ha}^{-1}$ in the upper $15 \mathrm{~cm}$ of the soil profile with an additional 7-12 $\mathrm{kg} \mathrm{NO}_{3}{ }^{-} \mathrm{ha}^{-1}$ from 16-60 $\mathrm{cm}$ depth in the soil profile. In Arkansas, Mississippi, and Tennessee there was 30-35 and 30-48 $\mathrm{kg} \mathrm{NO}_{3}{ }^{-} \mathrm{ha}^{-1}$ in the top $15 \mathrm{~cm}$ and $16-60 \mathrm{~cm}$ soil depths, respectively. In areas with little to no nitrogen use history (Kansas 2010, south Texas, and west Texas 2010) total nitrate found in a $60 \mathrm{~cm}$ profile was less than $20 \mathrm{NO}_{3}{ }^{-} \mathrm{ha}^{-1}$. More arid environments with nitrogen use history (Arizona and west Texas 2009) had greater than $130 \mathrm{~kg} \mathrm{NO}_{3}{ }^{-} \mathrm{ha}^{-1}$ in the 60 $\mathrm{cm}$ profile. Pre-sidedress Soil Nitrate Tests (PSNT) have shown promise in predicting N fertilizer needs for other crops. Spellman et al. (1998) reported that critical levels for $\mathrm{PSNT} \mathrm{NO}_{3}{ }^{-}$ for corn production were lower in semi-arid of the western U.S. than in more humid environments. Similar results were reported in Australia where soil $\mathrm{NO}_{3}{ }^{-}$levels sampled to a depth of $30 \mathrm{~cm}$ prior to planting were closely correlated to cotton $\mathrm{N}$ uptake in plots that received no applied $\mathrm{N}$ fertilizer (Constable and Rochester, 1988). While soil $\mathrm{NO}_{3}{ }^{-}$testing is not currently utilized to a great extent for cotton production, this type of testing could prove to be economically beneficial in areas where residual $\mathrm{NO}_{3}{ }^{-}$is present.

\section{Effects of Seed Size x N Rates}


Contrary to the hypothesis of this research, no interaction of seed size and $\mathrm{N}$ rate was found. The 60 site-year x variety means generated by this research represented a total of 18 varieties. All varieties were locally adapted and many were in the top 10 most commonly-planted varieties for the years when the experiments were conducted. Since no interactions of $\mathrm{N}$ rate and varieties was found, the data are presented as the main effects of seed-size and $\mathrm{N}$ rate.

\section{Effects of Seed Sizes}

When grown in these environments with four $\mathrm{N}$ application levels the varieties of the respective seed-size classes produced fuzzy seed that differed in mean weight (Table 2). Lint yields and mean seed size of commercial cotton varieties have varied inversely for the past 60 years (Culp and Harrell, 1975; Harrell and Culp, 1976; and Bednarz and Nichols, 2007), apparently in response to selection for high lint percentage and lint yield. Highest lint yields were observed in these experiments when varieties were of a medium seed size. (Table 2).

\section{Effects of N Rates}

At 11 of 20 trial sites there was a lint yield response to applied nitrogen. When $45 \mathrm{~kg} \mathrm{~N} \mathrm{ha}^{-1}$ was applied yields were greater than when no nitrogen was applied, but were less than yields where 90-134 $\mathrm{kg} \mathrm{N} \mathrm{ha}^{-1}$ was applied (Figure 2a). When all trial sites, both $\mathrm{N}$ responsive and nonresponsive, are considered $45 \mathrm{~kg} \mathrm{~N}$ ha $^{-1}$ increased yields above no applied $\mathrm{N}$, but additional $\mathrm{N}$ above $45 \mathrm{~kg} \mathrm{~N}^{-1} \mathrm{a}^{-1}$ did not improve lint yield.

\section{Effects of Applied N Rate Plus Soil Residual $\mathrm{NO}_{3}{ }^{-}$}

Cotton responds to ammonium and nitrate nitrogen from all sources, soil, water, and atmospheric deposition. While any measurement of soil nitrate is transient, measurement of pre-plant soil 
nitrate is a relatively simple and inexpensive way for a grower to estimate readily available soil nitrogen at planting (Hons et al., 2004). Accordingly, soil nitrate was measured at all sites. When applied $\mathrm{N}$ plus measured soil $\mathrm{NO}_{3}{ }^{-}$is considered with cotton lint response a more accurate relationship may be established. To make this comparison soil $\mathrm{NO}_{3}{ }^{-}$in the upper $60 \mathrm{~cm}$ of the soil profile plus applied $\mathrm{N}$ was categorized into $28 \mathrm{~kg} \mathrm{NO}_{3}{ }^{-} \mathrm{ha}^{-1}$ groups and analyzed for yield response (Figure 2b).

\section{Cotton Growth:}

Measurements of cotton plant growth and development indicate that $\mathrm{N}$ application rate effected plant height, total number of nodes and delayed crop maturity. Plant height ranges from $74.2 \mathrm{~cm}$ to $88.2 \mathrm{~cm}$ from 0 to $134 \mathrm{~kg} \mathrm{ha}^{-1} \mathrm{~N}$ application, respectively (Table 3). Similarly, the number of nodes increased with increasing $\mathrm{N}$ application growing an additional 1.9 nodes when comparing $134 \mathrm{~kg} \mathrm{ha}^{-1} \mathrm{~N}$ application to $0 \mathrm{~kg} \mathrm{ha}^{-1}$. The consequence of growing a taller plant with more nodes is extending the length of growing season needed to mature developing bolls. The addition of nitrogen delayed cotton maturity when NAWF was measured during the second week of bloom in these trials (data not shown). Additionally, higher levels of nitrogen fertilization delayed maturity at the end of the growing season (Table 2). There was a 1.6 NACB difference which would require 88 additional heat units, or approximately five days based on reports of Brecke et al. (2001).

\section{Lint Yields:}

Lint yields are presented as functions of applied N (Figure 2a) and as applied N plus measured soil $\mathrm{NO}_{3}{ }^{-}$(Figure $2 \mathrm{~b}$. .). Lint yields are shown separately for all test sites and for only those sites that had a significant response to applied nitrogen. Only 11 of the 20 sites responded to applied 
N. For all four cases, second degree polynomial regression was highly significant $(\mathrm{P}<0.01)$. For both applied $\mathrm{N}$ and applied plus measured soil $\mathrm{NO}_{3}{ }^{-}$, the coefficient of determination was increased when only $\mathrm{N}$ responding sites were considered for both applied $\mathrm{N}$ plus measured soil $\mathrm{NO}_{3}{ }^{-}$. For both $\mathrm{N}$ responding sites and all trial sites, a declining trend in lint yields was found when applied $\mathrm{N}$ plus soil $\mathrm{NO}_{3}{ }^{-}$was greater than 152 and $125 \mathrm{~kg} \mathrm{~N} / \mathrm{ha}$, respectively. Interestingly, when $0 \mathrm{~kg} \mathrm{~N} \mathrm{ha}^{-1}$ was applied in these trials the average lint yield was $1208 \mathrm{~kg} \mathrm{ha}^{-1}$ indicating that residual soil $\mathrm{NO}_{3}{ }^{-}$and other forms of soil $\mathrm{N}$ provide nutrition to the cotton crop.

For $\mathrm{N}$ responsive sites optimum lint yield response occurred between 112-224 $\mathrm{kg}$ applied $\mathrm{N}$ plus soil $\mathrm{NO}_{3}{ }^{-}$with negative yield trend above $196 \mathrm{~kg} \mathrm{~N} \mathrm{ha}^{-1}$. This represents $19-36 \mathrm{~kg} \mathrm{ha}^{-1}$ use per $218 \mathrm{~kg}$ bale of cotton lint with a regression maximum near $23 \mathrm{~kg}$ applied $\mathrm{N}$ plus soil $\mathrm{NO}_{3}{ }^{-} \mathrm{ha}^{-1}$. When all trial sites are considered, optimum lint yield response to applied $\mathrm{N}$ plus soil $\mathrm{NO}_{3}{ }^{-}$shifts lower in a range from 70-180 kg N ha ${ }^{-1}$. This represents $12-28 \mathrm{~kg} \mathrm{ha}^{-1} \mathrm{~N}$ use per $218 \mathrm{~kg}$ bale of cotton lint with a regression maximum near $19 \mathrm{~kg}$ applied $\mathrm{N} \mathrm{ha}^{-1}$. The difference in $\mathrm{N}$ utilization between responsive and non-responsive locations as well as the different conclusion for optimal $\mathrm{N}$ rate between applied $\mathrm{N}$ and applied $\mathrm{N}$ plus soil $\mathrm{NO}_{3}{ }^{-}$illustrates just a portion of the complexity in prescribing $\mathrm{N}$ rates. These data suggest that soil $\mathrm{NO}_{3}{ }^{-}$testing immediately prior to cotton planting can serve as a guide to help prevent over fertilization and yield loss, as well as protect water resources from $\mathrm{N}$ loading with excessive $\mathrm{N}$ applications.

In Figure 3 yield data is presented by soil type for $\mathrm{N}$ responsive locations and similar second degree polynomial regression indicted good to excellent response to applied $\mathrm{N}$ plus soil $\mathrm{NO}_{3}{ }^{-}$ based on coefficients of determination. Lint yield values were normalized to percentage of the highest yielding applied $\mathrm{N}$ plus soil $\mathrm{NO}_{3}{ }^{-}$category. Lint yield at locations with clay loam (36\% increase) and loam (75\% increase) soil types responded more to applied N. Lint yield from sites 
with Sandy loam, silt loam and silty clay loam soil responded to applied N plus soil N) ${ }_{3}{ }^{-}$levels however, the response ranged from a16-22\% increase.

\section{Seed and Fiber Properties:}

Significant effects of $\mathrm{N}$ application rate on mean fuzzy seed weights, gin turnout, fiber strength, fiber length uniformity, and micronaire were found (Table 2). Increasing $\mathrm{N}$ rates increased mean fuzzy seed weight compared to the $0 \mathrm{~kg} \mathrm{~N} \mathrm{ha}^{-1}$ rate. Although such an effect is familiar to many cotton researchers, these are the first data of which we are aware that definitely establish this relationship over multiple environments. Algebraically, an increase in mean seed weight would be expected to decrease lint percentage, and such a result was confirmed when applying 90 or $134 \mathrm{~kg} \mathrm{ha}^{-1} \mathrm{~N}$ decreased gin turnout. Plant vigor associated with good $\mathrm{N}$ management may be expected to positively influence fiber strength and an increase in strength was found when $\mathrm{N}$ was applied. Similarly fiber length uniformity also increased with increasing $\mathrm{N}$ rate. However, fiber micronaire decreased. Micronaire is an indirect measure influenced both by fiber fineness and fiber maturity, the latter being the degree of deposition of cellulose in the secondary cell wall inside the microfibril encasing the fiber lumen (DeLanghe, 1986). In this instance, we propose that the decrease is primarily due to the decrease in fiber maturity associated with the increase in late-season growth caused by abundant N nutrition (Boman and Westerman, 1994). Small differences in fiber properities were detected for the differing planting seed sizes. However, these differences are likely due to genetic differences among varieties than seed size.

As anticipated, higher applied $\mathrm{N}$ rate increased seed protein, but the effect was small. Conversely as seed protein increased, seed oil content decreased (Figure 4). Similar effects were observed when data was analyzed for applied $\mathrm{N}$ plus soil $\mathrm{NO}_{3}^{-}$(data not shown). No differences were 
noted for seed protein or seed oil content for varieties of different seed sizes. This indicates that while seed protein and seed oil content can be affected by $\mathrm{N}$ application, the concentrations remain relative to seed mass.

\section{Conclusions and Recommendations}

Residual soil $\mathrm{NO}_{3}{ }^{-}$is present in cotton belt soils. When nitrogen is applied cotton plants grow taller, develop more nodes and the time to crop maturity was increased in these trials. Cotton planting seed size did not interact with applied $\mathrm{N}$ rates. Increasing applied $\mathrm{N}$ rate increased seed index, fiber length, fiber length uniformity, fiber strength while lint percentage and fiber micronaire decreased.

Cotton lint yield responded to applied $\mathrm{N}$ in 11 of 20 trails included in this data set. Lint yield was increased at responsive locations by $45 \mathrm{~kg} \mathrm{~N} \mathrm{ha}^{-1}$ compared to plots receiving $0 \mathrm{~kg} \mathrm{~N} \mathrm{ha}^{-1}$. Similarly applications of 90 and $134 \mathrm{~kg} \mathrm{~N} \mathrm{ha}^{-1}$ increased lint yield compared $45 \mathrm{~kg} \mathrm{~N}^{-1}$. When applied $\mathrm{N}$ plus residual soil $\mathrm{NO}_{3}{ }^{-}$are considered location that had a response to applied $\mathrm{N}$ maximized lint production near $150 \mathrm{~kg}$ applied $\mathrm{N}$ plus soil $\mathrm{NO}_{3}{ }^{-} \mathrm{ha}^{-1}$. This translates to an $\mathrm{N}$ requirement of $23 \mathrm{~kg} \mathrm{ha}^{-1}$ for each $218 \mathrm{~kg}$ bale of lint produced. This research indicates that measuring soil residual $\mathrm{NO}_{3}{ }^{-}$may help reduce $\mathrm{N}$ input costs and $\mathrm{N}$ loading in the environment while maintaining high levels of productivity.

While the data cannot be extrapolated to every cotton variety, we conclude that these data are sufficient to make an $\mathrm{N}$ recommendation of $23 \mathrm{~kg} \mathrm{~N}$ ha $^{-1}$ per bale of expected yield including applied $\mathrm{N}$ plus residual soil $\mathrm{NO}_{3}{ }^{-}$measurements immediate prior to planting. This recommendation should be sufficient for contemporary cotton varieties in the absence of other data to the contrary for an individual variety. 


\section{$\underline{\text { Literature Cited }}$}

Bednarz, C. W. and R. L. Nichols. 2005. Phenological and morphological components of cotton crop maturity. Crop Sci. 45:1497-1503.

Bednarz, C. W., R. L. Nichols, S. M. Brown. 2007. Within-boll yield components of high yielding cotton cultivars. Crop Sci. 47:2108-2112.

Blouin, D. C., E. P. Webster, and J. A. Bond. 2011. On the analysis of combined experiments. Weed Technol. 25:165-169.

Boman, R. K. and R . L. Westerman. 1994. Nitrogen and mepiquat chloride effects on the production of nonrank, irrigated, short-season cotton. J. Prod. Agric. 7:70-75.

Bond, J.A., T.W. Walker, P.K. Bollich, C.H. Koger, and P.D. Gerard. 2005. Seeding rates for stale seedbed rice production in the midsouthern United States. Agron. J. 97:1560-1563.

Bond, J.A., T.W. Walker, B.V. Ottis, and D.L. Harrell. 2008. Rice seeding and nitrogen rate effects on yield and yield components of two rice cultivars. Agron. J. 100:393- 397.

Boquet, D. J., E. B. Moser, and G. A. Breitenbeck. 1993. Nitrogen effects on boll production of field-grown cotton. Agron. J. 85:34-39.

Boquet, D. J., E. B. Moser, and G. A. Breitenbeck. 1994. Boll weight and within-plant yield distribution in field-grown cotton given different levels of nitrogen. Agron. J. 86: 20-26

Boquet, D. J. and G. A. Breitenbeck. 2000. Nitrogen rate effect on nitrogen and dry matter by cotton. Crop. Sci. 40:1685-1693.

Bourland, F. M., D. M. Oosterhuis, and N. P. Tugwell. 1992. Concept for monitoring the growth and development of cotton plants using main-stem node counts. J. Prod. Agric. 5:532-538.

Bourland, F. M., Benson, N. R., Vories, E. D., Tugwell, N. P., and Danforth, D. M. 2001. Measuring maturity of cotton using nodes above white flower. J. Cotton Sci. 5:1-8. 
Brecke, B.J., J.C. Banks, J.T, Cothren. 2001. Harvest-aid treatments; products and application timing. In J.R. Mauney and J.M. Stewart. eds. Cotton Physiology. The Cotton Foundation Reference Book Series Number 1, Memphis, TN 786 pages.

Bremner, J. M. 1965. Inorganic forms of nitrogen. pp. 1179-1255. In C. A. Black et al. eds. Methods of Soil Analysis Part 2. Chemical and Microbiological Properties. American Society of Agronomy Number 9. Madison, WI. 1572 pages.

Bronson, K.F., A.B. Onken, J.W. Keeling, J.D. Booker, and H.A. Torbet. 2001. Nitrogen response in cotton as affected by tillage system and irrigation level. Soil Sci. Soc. Am. J. 65:1153-1163.

Carmer, S.G., W.E. Nyquist, and W.M. Walker. 1989. Least significant differences for combined analysis of experiments with two- or three-factor designs. Agron. J. 81:665-672.

Constable, G.A. and I.J. Rochester. 1988. Nitrogen Application to Cotton on Clay Soil: Timing and Soil Testing. Agron. J. 80:498-502.

Culp, T. W. and D. C. Harrell. 1975. Influence of lint percentage, boll size, and seed size on lint yield of upland cotton with high fiber strength. Crop Science 15-741-746.

DeLanghe, E.A.L. 1986. Lint development. In J.r. Supak and C.E. Snipes eds. Cotton Physiology. The Cotton Foundation Reference Book Series Number 5, Memphis, TN. 786 pages.

Donald, C.M. and J. Hamblin. 1976. The biological yield and harvest index of cereals as agronomic and plant breeding material criteria. Adv. Agon. 28:361-405.

Engelkraut, T. M., D. E. Kissel, M. L. Cabrera, G. J. Gascho, and W. Adkins. 2004. Nitrogen concentration in cottonseed as an indicator of $\mathrm{N}$ availability. Nutr. Cycl. Agroecosys. 68:235-242. 
Fritschi, F. B., B. A. Roberts, R. L. Travis, D. W. Rains, and R. B. Hutmacher. 2003. Response of irrigated Acala and Pima cotton to nitrogen fertilization: growth, dry matter partitioning, and yield. Agron. J. 95:133-146.

Galloway, J. N., A. R. Townsend, J. W. Erisman, M. Bekunda, Z. Cai, J. R. Freney, L. A. Martinelli, S. P. Seitzinger, and M. A. Sutton. 2008. Transformation of the nitrogen cycle: recent trends, questions, and potential solutions. Science 320: 889-892.

Hager, A.G., L.M. Wax, G.A. Bollero, and E.W. Stoller. 2003. Influence of diphenylether herbicide application rate and timing on common waterhemp (Amaranthus rudis) control in soybean (Glycine max). Weed Technol. 17:14-20.

Harrell, D. C. and T. W. Culp. 1976. Effects of yield components on lint yield of upland cotton with high fiber strength. Crop Sci. 16:205-208.

Hons, F. M., M. L. McFarland, R. G. Lemon, R. L. Nichols, R. K. Boman, V. A. Saladino, F. J. Maza Jr., R. L. Jahn, and J. R. Stapper. 2004. Managing Nitrogen Fertilization in Cotton. Texas Cooperative Extension Bulletin L-5458. 4 pages.

Horn P. J., P. Neogi, X. Tombokan, S. Ghosh, B. T. Campbell, and K. D. Chapman. 2011. Simultaneous quantification of oil and protein in cottonseed by low-field time-domain nuclear magnetic resonance. J Amer Oil Chem Soc. 88:1521-1529.

Hunt, P. G., P. J. Bauer, C. R. Camp, and T. A. Matheny. 1998. Nitrogen accumulation in cotton grown continuously or in rotation with peanut using subsurface microirrigation and GOSSYM/COMAX Management. Crop Sci. 38:410-415. 
Hutmacher, R. B. R. L. Travis, R. L. Nichols, D. E. Rains, B. A. Roberts, B. L. Weir, R. N. Vargas, B. H. Marsh, S. D. Wright, D. S. Munk, D. J. Munier, M. P. Keeley, F. Fritschi, R. L. Delgado, and S. Perkins. 2001. Response of Acala cotton to nitrogen rates in the San Joaquin Valley of California. Proceeding of the Second International Nitrogen Management Conference. The Scientific World, 1(S2) p. 691-698.

(http://www.thescientificworld.com)

Hutmacher, R. B., R. L. Travis, D. W. Rains, R. N. Vargas, B. A. Roberts, B. L. Weir, S. D. Wright, D. S. Munk, B. H. Marsh, M. P. Keely, F. B. Fritschi, D. J. Munier, R. L. Nichols, and R. Delegado. 2004. Response of recent Acala cotton varieties to variable nitrogen rates in the San Joaquin Valley of California. Agron. J. 96:48-62.

Jenkins, J.N., J.C. McCarty, and W.L. Parrot. 1990. Effectiveness of fruiting sites in cotton yield. Crop Sci. 30:365-369.

Mullins, G. L. and Burmeister, C. H. 1990. Dry matter, nitrogen, phosphorus, and potassium accumulation by four cotton varieties. Agron. J. 82:52-56.

Nichols, R. L. and C. J. Green. 2003. Estimating Cotton’s Nitrogen Needs. Proc. Beltwide Cotton Conferences. p. 175-178. Natl. Cotton Counc. Am., Memphis, TN.

Ottis, B.V., J.H. O’Barr, G.N. McCauley, and J.M. Chandler. 2004. Imazethapyr is safe and effective for imidazolinone-tolerant rice grown on course-textured soils. Weed Technol. 18:1096-1100.

Sasser, P. E. 1981. The basics of high volume instruments for fiber testing. 1981. In Proc. Beltwide Cotton Conf., p.191-193. Natl. Cotton Counc. Am., Memphis, TN. 
Spellman, D.E., A. Rongni, D. G. Westfall, R. M. Waskom, P. N. Soltanpour. 1996. Presidedress nitrate soil testing to manage nitrogen fertility in irrigated corn in a semi-arid environment. Commun. Soil Sci. Plant. 27:3-4, 561-574.

Walker, T.W., J.A. Bond, B.V. Ottis, P.D. Gerard, and D.L. Harrell. 2008. Hybrid rice response to nitrogen fertilization for midsouthern United States rice production. Agron. J. 100:381386.

USDA-Economic Research Service. 2012. Fertilizer use and price. Website: http://www.ers.usda.gov/Data/FertilizerUse/. Accessed: January 18, 2012. 


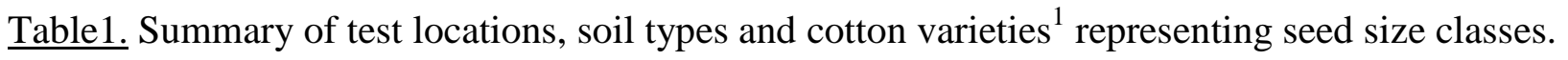

\begin{tabular}{lcllll}
\hline & & & \multicolumn{1}{c}{ Seed Sizes } \\
\cline { 3 - 6 } Location & Years & \multicolumn{1}{c}{ Soil Type } & \multicolumn{1}{c}{ Small } & \multicolumn{1}{c}{ Medium } & Large \\
\hline Arkansas & $2009-2010$ & Silt Loam & ST 5288B2F & DP 0924 B2RF & FM 1740B2RF \\
Arizona & 2009 & Clay Loam & DP 164 B2RF & ST 4498B2RF & PHY 745 WRF \\
& 2010 & Clay Loam & ST 5288B2F & DP 0924 B2RF & FM 1740B2RF \\
Georgia & 2009 & Sandy Loam & DP 555 BG/RR & PHY 485 WRF & FM 1740B2RF \\
Kansas & 2010 & Sandy Loam & ST 5288B2F & DP 0924 B2RF & FM 9180B2F \\
Mississippi & $2009-2010$ & Loam & ST 5288B2F & DP 0924 B2RF & FM 1740B2RF \\
North Carolina & $2009-2010$ & Sandy Loam & ST 5288B2F & DP 0912 B2RF & FM 1740B2RF \\
Oklahoma & 2009 & Clay Loam & DP 164 B2RF & ST 4554B2RF & FM 9180B2F \\
South Carolina & $2009-2010$ & Sandy Loam & ST 5288B2F & DP 0924 B2RF & FM 9180B2F \\
Tennessee & $2009-2010$ & Silt Loam & DP 555 BG/RR & DP 0935 B2RF & PHY 745 WRF \\
South Texas & $2009-2010$ & Silty Clay Loam & DP 5288B2F & DP 0920 B2RF & FM 1740B2RF \\
West Texas & 2009 & Clay Loam & DP 161 B2RF & FM 9058F & FM 840B2F \\
& 2010 & Clay Loam & ST 5288B2F & DP 0924 B2RF & FM 9180B2F \\
\hline
\end{tabular}

${ }^{1}$ DP $=$ Deltapine, Monsanto Company, 800 N. Lindbergh Blvd., St. Louis, MO 63167

FM = FiberMax, Bayer CropScience, 2 TW Alexander Drive, Research Triangle Park, NC 27709

PHY = PhytoGen Cotton Seed, Dow AgroSciences LLC, 9330 Zionsville Road, Indianapolis, IN 46268

ST = Stoneville, Bayer CropScience, 2 TW Alexander Drive, Research Triangle Park, NC 27709 
Table 2. Effect of applied nitrogen rate and cotton planting seed size on lint, fuzzy seed size and fiber quality parameters.

\begin{tabular}{|c|c|c|c|c|c|c|c|c|}
\hline $\begin{array}{c}\text { Nitrogen } \\
\text { kg/ha }\end{array}$ & $\begin{array}{l}\text { Seed } \\
\text { Size }\end{array}$ & $\begin{array}{c}\text { Lint } \\
\text { kg ha }^{-1}\end{array}$ & $\begin{array}{c}\text { Seed wt } \\
\text { g } 100 \text { seed }^{-1} \\
\end{array}$ & $\begin{array}{c}\text { GTO } \\
\% \\
\end{array}$ & Mic & $\begin{array}{l}\text { length } \\
\text { in. }\end{array}$ & $\begin{array}{c}\text { strength } \\
\text { g/tex }\end{array}$ & $\begin{array}{c}\text { uni } \\
\%\end{array}$ \\
\hline 0 & & 1208 & 9.08 & 38.6 & 4.7 & 1.12 & 28.8 & 81.8 \\
\hline 45 & & 1368 & 9.27 & 38.3 & 4.6 & 1.11 & 29.0 & 81.9 \\
\hline 90 & & 1435 & 9.30 & 38.1 & 4.6 & 1.12 & 29.2 & 82.0 \\
\hline 134 & & 1447 & 9.37 & 37.6 & 4.5 & 1.12 & 29.3 & 82.2 \\
\hline \multirow[t]{5}{*}{$\operatorname{LSD}(0.05)$} & & 64 & 0.19 & 0.4 & 0.1 & 0.01 & 0.3 & ns \\
\hline & Large & 1327 & 9.65 & 37.9 & 4.5 & 1.13 & 29.4 & 82.3 \\
\hline & Medium & 1410 & 9.33 & 38.7 & 4.7 & 1.11 & 28.5 & 82.3 \\
\hline & Small & 1357 & 8.80 & 38.5 & 4.6 & 1.12 & 28.9 & 81.8 \\
\hline & $\operatorname{LSD}(0.05)$ & 55 & 0.16 & 0.3 & 0.1 & 0.01 & 0.3 & 0.2 \\
\hline
\end{tabular}


Table 3. Effect of nitrogen application rate on cotton growth and maturity.

\begin{tabular}{lccc}
\hline $\begin{array}{l}\text { Nitrogen } \\
\text { kg/ha }\end{array}$ & $\begin{array}{c}\text { Plant height } \\
\text { cm }\end{array}$ & $\begin{array}{c}\text { Plant nodes } \\
\text { no. }\end{array}$ & $\begin{array}{c}\text { NACB } \\
\text { no. }\end{array}$ \\
\hline 0 & 74.2 & 16.6 & 4.3 \\
45 & 79.8 & 17.1 & 4.9 \\
90 & 84.1 & 18.0 & 5.3 \\
134 & 88.2 & 18.5 & 5.9 \\
\hline LSD (0.05) & 2.3 & 1.0 & 0.5 \\
\hline
\end{tabular}

${ }^{1}$ Node number above highest first position cracked boll to highest harvestable first position boll. 
Figure 1. Pre-plant residual soil $\mathrm{NO}_{3}{ }^{-}$by trial location.

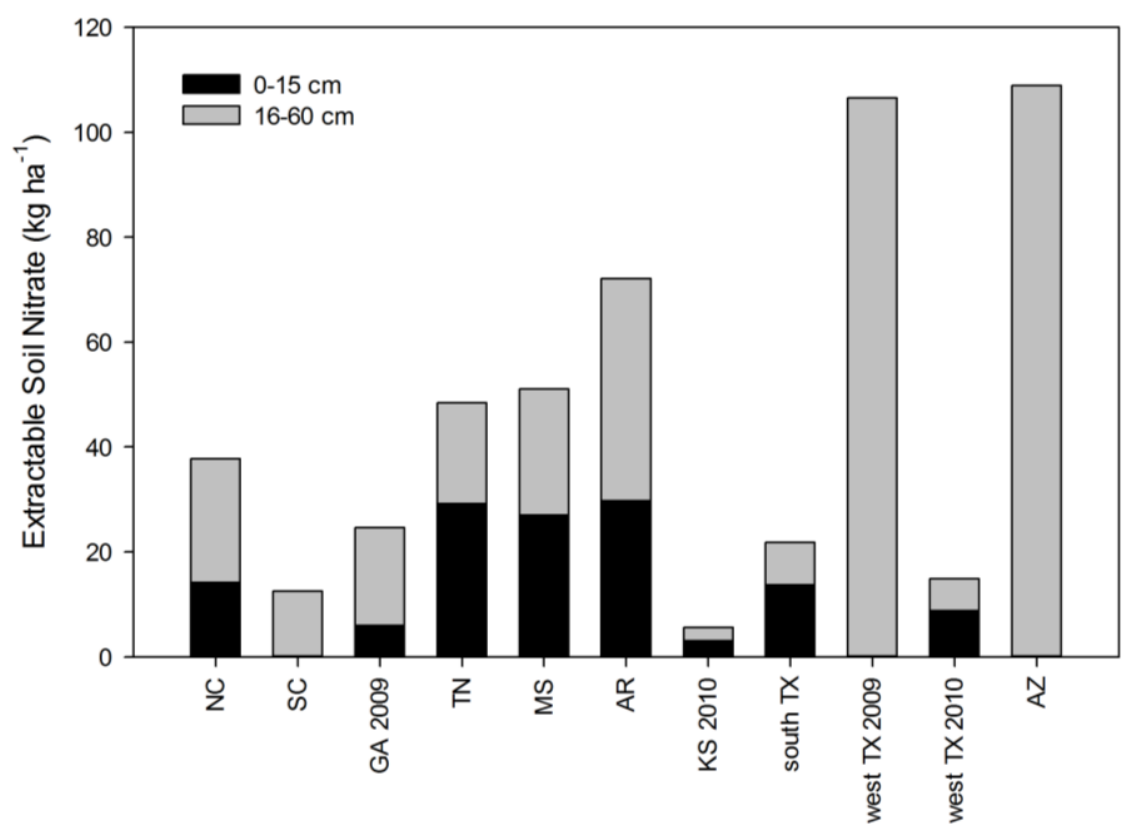

Trial Location 
Figure $2 \mathrm{a}$ and $\mathrm{b}$. Effect of applied nitrogen and measured pre-plant soil $\mathrm{NO}_{3}{ }^{-}$on cotton lint yield at all test sites and only those that responded to applied nitrogen.

\section{Figure 2a.}

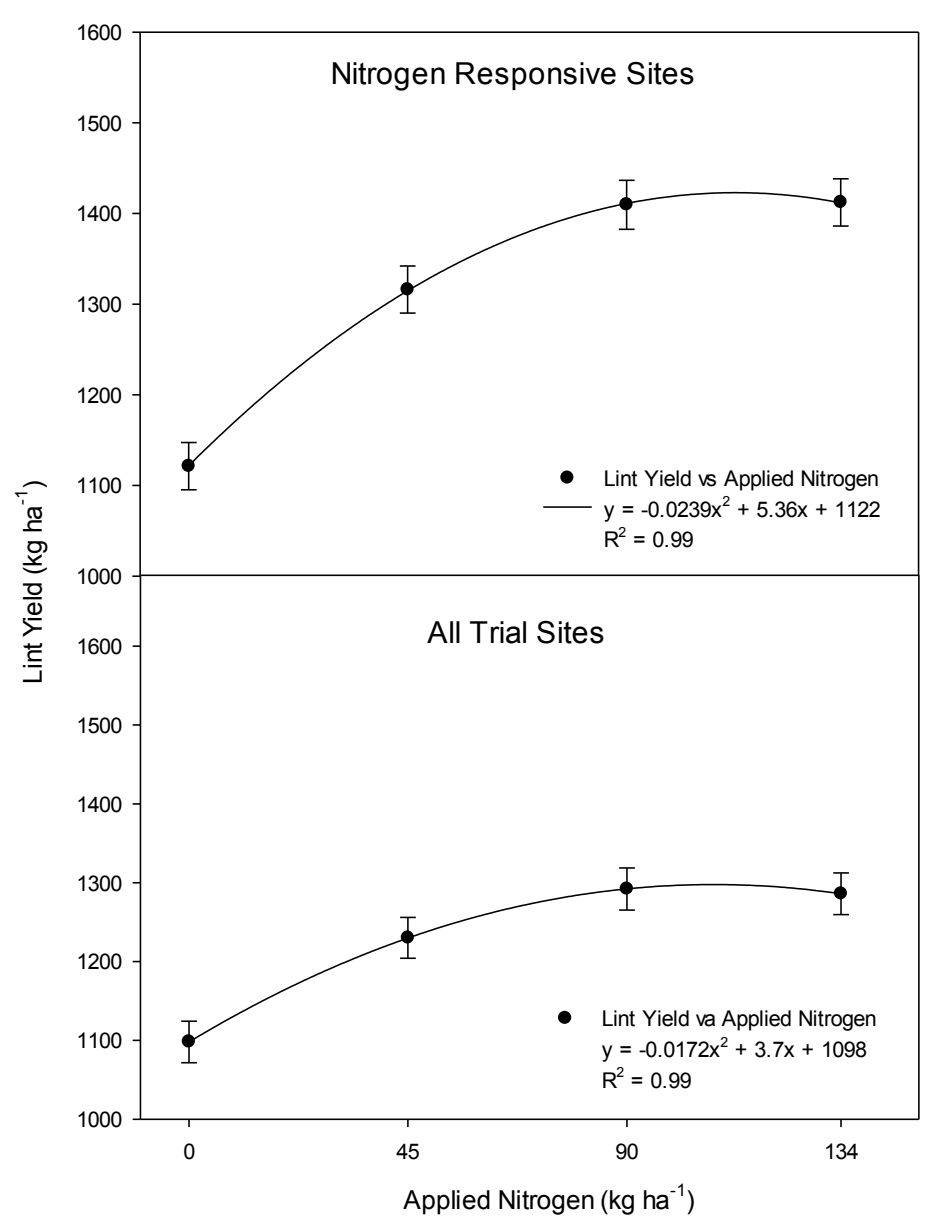

Figure $2 \mathrm{~b}$.

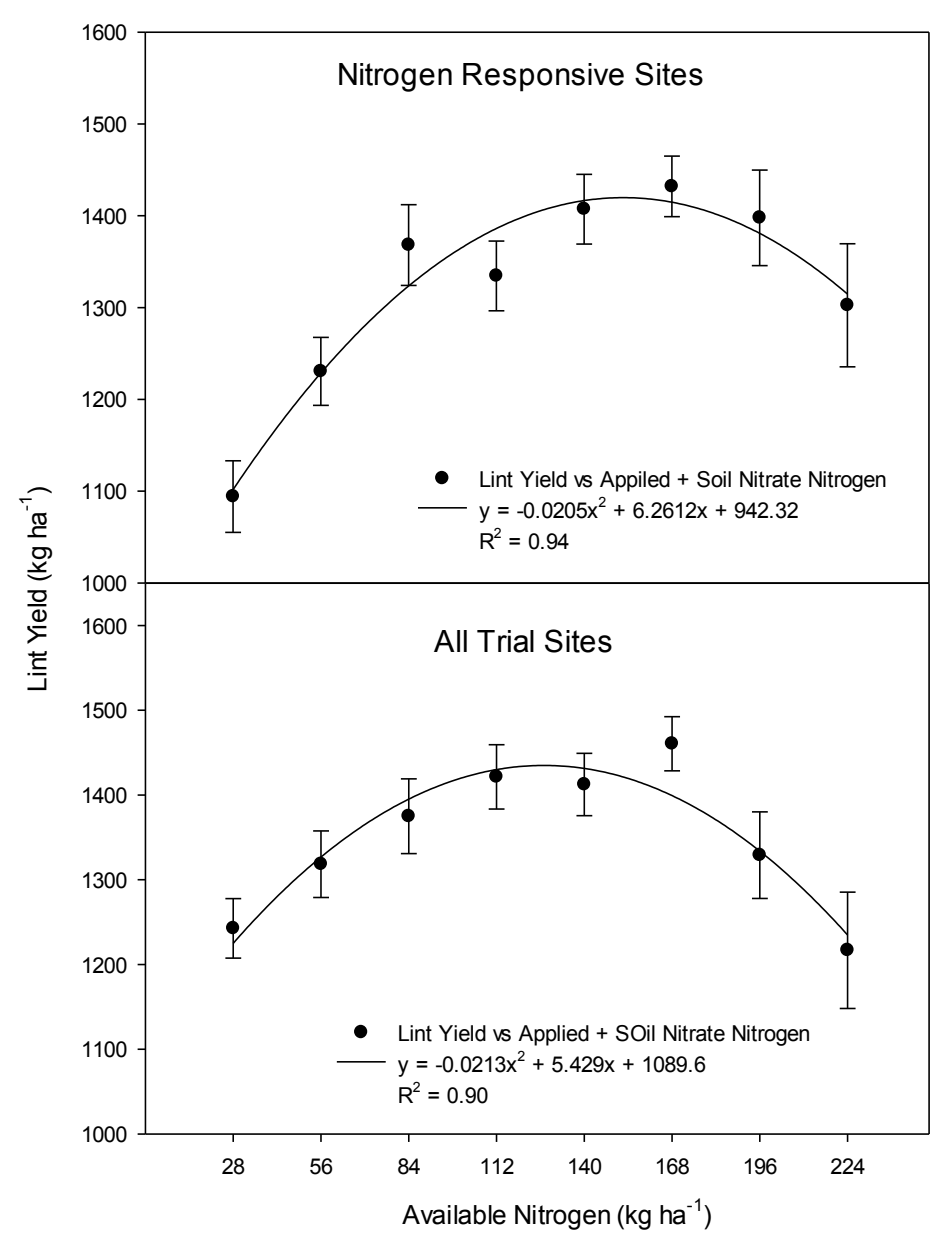


Figure 3. Cotton lint yield response to applied nitrogen plus residual soil $\mathrm{NO}_{3}{ }^{-}$by soil type normalized to highest yielding treatment.

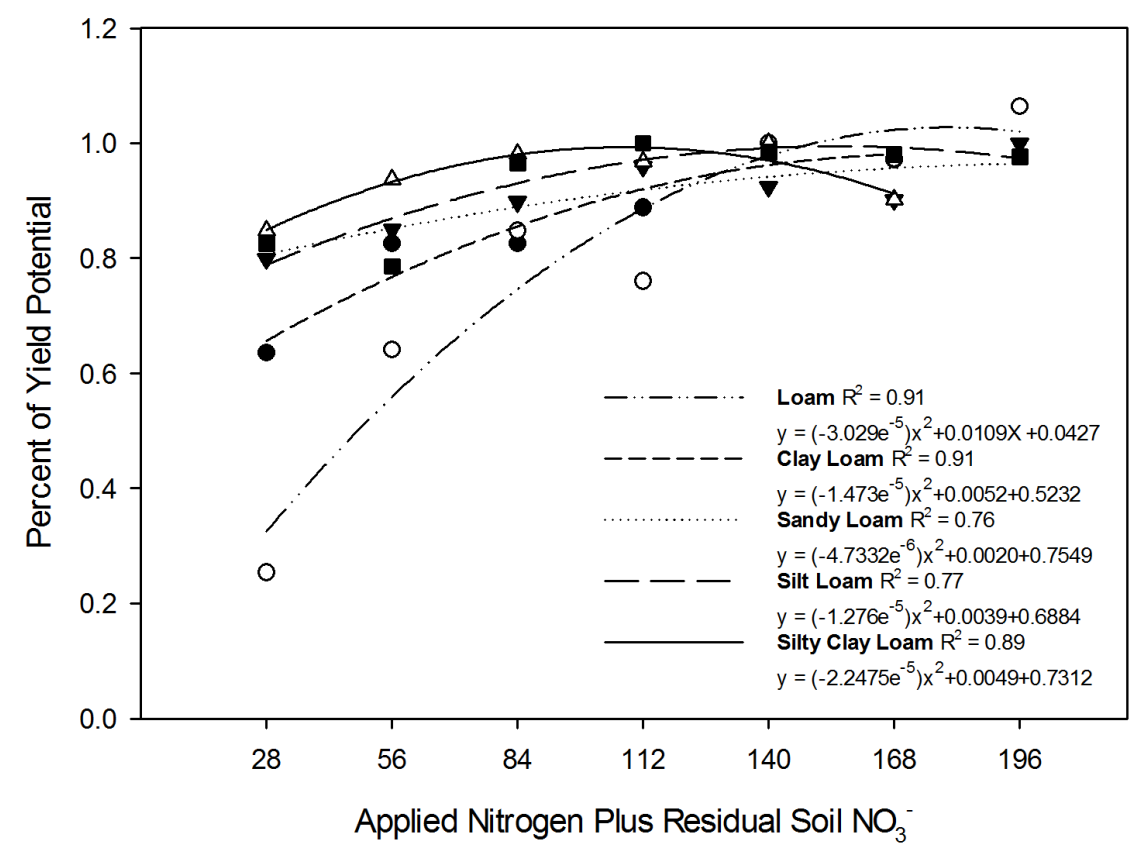


Figure 4. Relation of seed protein and oil content to applied nitrogen rates.

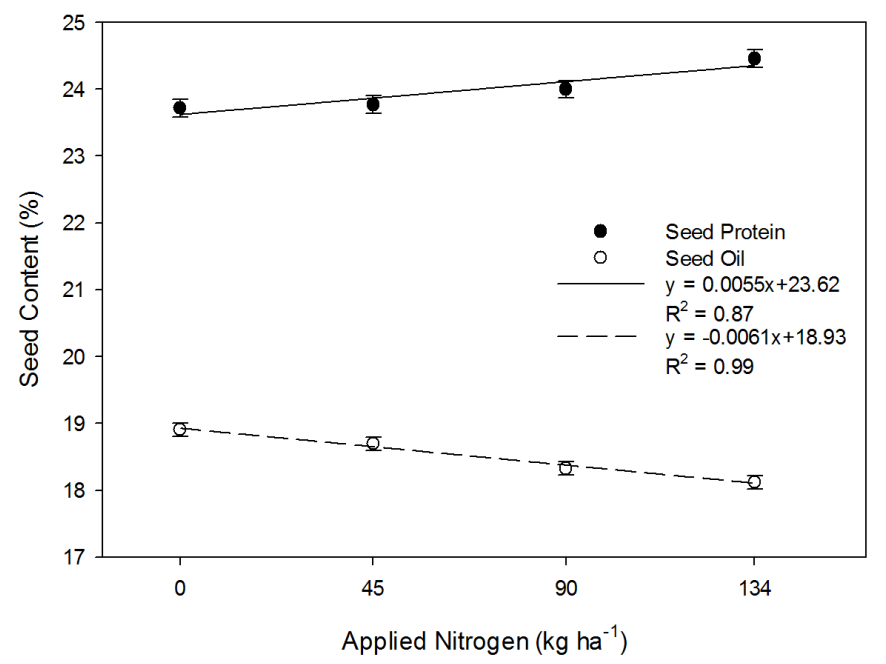

